\section{(2) OPEN ACCESS}

\title{
UK tobacco price increases: driven by industry or public health?
}

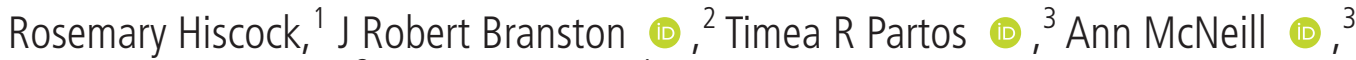 \\ Sara C Hitchman (10, ${ }^{3}$ Anna B Gilmore ${ }^{1}$
}

${ }^{1}$ Tobacco Control Research Group, Department for Health, University of Bath, Bath, UK

${ }^{2}$ School of Management, University of Bath, Bath, UK ${ }^{3}$ Department of Addictions, Institute of Psychiatry, Psychology and Neuroscience, Kings College London, London, UK

\section{Correspondence to} Dr J Robert Branston, School of Management, University of Bath, Bath BA2 7AY, UK; J.R.Branston@bath.ac.uk

Received 25 January 2019 Revised 9 May 2019 Accepted 16 May 2019 Published Online First 25 July 2019

\section{ABSTRACT}

Background Tobacco companies claim that higher taxes will force smokers into buying illicit tobacco, but if they were truly concerned about increasing illicit sales with higher prices they would only increase retail prices in line with changes in taxation. In this paper, we explore UK pricing of both factory-made cigarettes (FM) and roll-your-own tobacco (RYO) to explore the extent to which price increases were due to government tax rises or industry strategies to increase profit per pack.

Method Nielsen commercial data on UK tobacco sales data (2010-2015) were combined with official UK data on inflation and tax rates, to identify the source of real price increases.

Results Between 2010 and 2012, when there were unexpected large tax increases, industry driven price changes were small (16\% of the price rise in $\mathrm{FM}$ and $20 \%$ in RYO), and changes were similar between market segments. Between 2013 and 2015, when tax increases were smaller and expected, industry behaviour generally accounted for a larger share of price rises (33\% FM, $48 \%$ RYO), but changes varied considerably by segment.

Conclusion The industry has increased its prices beyond that required by tax changes, even when tax rises were larger and unexpected, although were notably smaller in such conditions. This suggests (1) that the industry is not actually concerned by the threat of illicit, especially since RYO had the highest levels of industry driven price increases despite higher levels of illicit, and (2) there remains scope for further tax increases, which should be relatively large and unexpected.

\section{INTRODUCTION}

Higher retail prices, often created by tobacco taxes, are one of the most effective ways of reducing tobacco use and hence the associated harms to health. ${ }^{1-3}$ However, as part of their lobbying effort against tobacco tax increases, the tobacco industry claim the resulting higher prices will force smokers into buying illicit tobacco. ${ }^{4-7}$ The tobacco industry also claim they want to combat illicit ${ }^{8}$ and if the industry were truly concerned that high prices increased it, they would only increase retail prices in line with changes in taxation, particularly given their already high level of profitability. ${ }^{9-11}$ Yet, it has previously been found that in the years up to 2010 , in both Britain ${ }^{6}$ and Ireland, ${ }^{7}$ that the tobacco industry regularly increased cigarette prices over and above the level required by increases in taxes (ie, they overshifted the tax increases) such that, in the UK, $\sim 50 \%$ of the price increase was attributable to industry price rises.
Since 2010 tobacco taxation has increased considerably in the UK. ${ }^{12}$ For instance, the taxation of roll-your-own tobacco (RYO) increased from $£ 129.59 / \mathrm{kg}$ in March 2010 to $£ 185.71 / \mathrm{kg}$ in March 2015. During this time, RYO also gained considerable market share. ${ }^{13}$ For instance, between 2009 and 2015 RYO sales increased by 46\%, while factory-made cigarettes (FM) declined by $17 \%,{ }^{14}$ such that exclusive RYO had a market share of $26 \%$ by $2015 .^{13}$ This increase in the market share of RYO reflects its lower rate of taxation and lower prices, ${ }^{13}$ yet there has been reluctance to increase taxes on RYO further because of fears about illicit given that a higher proportion of the RYO market $(28 \%$ in $2016 / 2017)$ than FM market (15\% in 2016/2017) in the UK comprises illicit product. ${ }^{15}$ Furthermore, in countries like the UK where tobacco is already relatively expensive and where tobacco sales are declining, it has been speculated that the industry's profitability model of overshifting taxes to enhance profit per stick, is becoming unsustainable. ${ }^{16}$

In this paper, our contribution is to update our previous analysis of UK tobacco pricing ${ }^{6} 14$ in order to explore the extent to which price increases were due to government tax rises and/or due to industry strategies to increase net revenue (and hence profit) per pack. Doing so will allow us to explore whether the industry really is concerned by higher prices driving illicit, and if they have continued to be able to enhance their profits per unit sold. For the first time, the analysis is extended to cover both FM and RYO given its increasing market share and higher illicit market.

\section{METHOD AND DATA SOURCES}

The price of a cigarette pack can be divided into two elements: government tax and industry revenue. We calculated (by-product type RYO or FM, and by price segment ${ }^{14}$ ) the proportion of the change in pack price attributable to these two elements for two 3-year time periods: 2010-2012, and 2013-2015. This was done by calculating average weighted price for each product/segment using individual brand level data weighted by volumes sold, and then by subtracting that segment's price at the beginning of the period from the price at the end. Price changes required to exactly offset changes in taxation were calculated for each segment, and this change was compared with the price changes that actually took place. We separated the time period in this way, as the former period included unexpected large tax increases and a change in tax structure towards specific taxes, whereas in the latter period there were regular but smaller tax increases that were set
To cite: Hiscock R,
Branston JR, Partos TR, et al. Tob Control

2019;28:e148-e150. 
Table 1 Weighted real price changes in pack revenue and tax — popular pack sizes in UK 2010-2015

\begin{tabular}{|c|c|c|c|c|c|}
\hline & $\begin{array}{l}\text { Total price increase } \\
\text { (f) }\end{array}$ & $\begin{array}{l}\text { Government tax increase } \\
\text { (f) }\end{array}$ & $\begin{array}{l}\text { Tobacco industry } \\
\text { revenue increase }(\mathrm{f})\end{array}$ & $\begin{array}{l}\% \text { of price change that is } \\
\text { government tax }\end{array}$ & $\begin{array}{l}\% \text { of price change that is } \\
\text { tobacco industry revenue }\end{array}$ \\
\hline \multicolumn{6}{|c|}{$\begin{array}{l}\text { January } 2010 \text { to December } \\
2012 \alpha\end{array}$} \\
\hline FM mid-price 20 stick & 0.96 & 0.81 & 0.15 & 84 & 16 \\
\hline FM value 20 stick & 1.12 & 0.93 & 0.19 & 83 & 17 \\
\hline RYO premium $12.5 \mathrm{~g}$ & 0.58 & 0.47 & 0.11 & 81 & 19 \\
\hline RYO mid-price $12.5 \mathrm{~g}$ & 0.60 & 0.47 & 0.13 & 78 & 22 \\
\hline RYO value $12.5 \mathrm{~g}$ & 0.55 & 0.45 & 0.10 & 82 & 18 \\
\hline Total RYO* & & & & 80 & 20 \\
\hline \multicolumn{6}{|c|}{$\begin{array}{l}\text { January } 2013 \text { to December } \\
2015 \beta\end{array}$} \\
\hline FM subvalue 19 stick & 0.37 & 0.43 & -0.06 & 116 & -16 \\
\hline Total FM* & & & & 67 & 33 \\
\hline RYO premium $12.5 \mathrm{~g}$ & 0.64 & 0.30 & 0.34 & 47 & 53 \\
\hline RYO mid-price $12.5 \mathrm{~g}$ & 0.55 & 0.29 & 0.26 & 52 & 48 \\
\hline RYO value $12.5 \mathrm{~g}$ & 0.39 & 0.25 & 0.14 & 64 & 36 \\
\hline Total RYO* & & & & 52 & 48 \\
\hline
\end{tabular}

$\alpha$ As of 31 March $2011 \mathrm{f1}=$ US\$1.603..$^{21}$

B As of 31 March $2014 \mathrm{f1}=$ US $\$ 1.6672 .^{22}$

${ }^{*}$ Weighted for volume, popular pack sizes only.

FM, factory-made cigarettes; RYO, roll-your-own tobacco.

years in advance (see table 1 in ${ }^{14}$ for full details). Cigarette price and segment information was sourced from our previous analysis of the most popular UK pack sizes using commercial point of sale data collated by Nielsen (see ${ }^{14}$ for full details). All prices were adjusted to real prices by removing the impact of inflation using the UK government's official Consumer Price Index (CPI) measure of inflation, with November 2008 used as the base month (due to the years covered in our previous study). Detail of prevailing tax rates were sourced from the UK government, ${ }^{18} 19$ and inflation data from the UK Office for National Statistics. ${ }^{20}$

\section{RESULTS}

In 2010-2012, the proportion of the price increase attributable to tax increases and industry price/revenue increases did not differ substantially by price segment or product type (despite tax and price increases being greater, in absolute terms, for FM than for RYO). For both FM and RYO increases in industry revenue accounted for about a fifth of the total price increase with little variation (14\%-22\%), and government revenues for the remainder $(\sim 80 \%)$.

In 2013-2015, however, the patterns were quite different. First, government tax, industry revenue and total price increases varied much more substantially by price segment. Larger absolute tax and price increases were seen in higher price segments for both FM and RYO. Furthermore, the impact of the differential tax increases was exacerbated by industry actions, with the industry adding 53 pence to the price of FM premium brands but cutting subvalue brands' prices by 6 pence, and in RYO adding 34 pence to RYO premium but only 14 pence to $\mathrm{RYO}$ value. Consequently, a roughly twofold difference in tax increase (43 p (FM subvalue) to $76 \mathrm{p} \mathrm{(FM} \mathrm{premium))} \mathrm{translates}$ to a more than threefold difference in price increase ( $37 \mathrm{p}$ to
$£ 1.29$, respectively) between FM segments. The percentage increase in overall total FM and overall total RYO price attributable to increases in industry revenue was higher in this period than the previous period. On average, about a third of the price increase for FM was industry revenue (compared with $16 \%$ in the previous period), while about half of the increase for RYO was industry revenue (compared with $20 \%$ in previous period).

\section{DISCUSSION/IMPLICATIONS}

There are three implications from our analysis of the proportion of the price increase attributable to industry revenue generation rather than tax increases.

First, for all price segments (apart from the FM subvalue segment in 2013-2015 when this was seemingly being promoted by the industry ${ }^{14}$ ) the tobacco industry was overshifting taxes, indicating that the industry was not concerned sufficiently about its alleged threat of illicit to avoid price increases. This implies that the industry does not believe their own argument that higher taxes/prices encourage illicit tobacco purchasing. This is further supported by a higher proportion of the total price increase being attributable to industry revenue increases for RYO (rather than FM), despite the illicit market share for RYO being substantially higher. ${ }^{15}$

Second, in the first period, where there were sudden large tax increases, compared with the second period, where there were planned and consistent smaller tax increases, the industry was less able to game the system by overshifting taxes on the more expensive products and absorbing taxes (undershifting) on cheaper products (both FM and RYO). The ability of the industry to do this is bad for public health as it means smokers are not faced with a quit-inducing sudden jump in retail prices. This implies that sudden unexpected and large tax increases compromise the 


\section{Box 1 What this paper adds}

- Higher retail prices, often created by tobacco taxes, are one of the most effective ways of reducing tobacco use and hence the associated harms to health.

- The tobacco industry argument for not increasing taxes states that rising prices will increase the use of illicit tobacco.

- To prevent smokers turning to illicit we would consequently expect the tobacco industry not to raise prices beyond meeting tax increases.

- The extent to which price rises are driven by government tax increases and/or industry revenue increases was not known.

- We found that even in the high tax environment of the UK, the industry has generally increased its prices beyond that required by tax changes.

- When there were unexpected large tax increases, industry driven price changes were small, and changes were similar between market segments.

- When tax increases were smaller and expected, industry behaviour generally accounted for a larger share of price rises but changes varied considerably by segment.

tobacco industry's ability to manipulate prices, and hence should become a key feature of future tobacco taxation.

Third, since overshifting continually occurred even when prices were already relatively high and tax rises were substantial, the results suggest there is still scope for further tax rises. If the industry is still able to increase its revenue (and hence profits) per pack, then government should be able to further increase taxes in order to deal with the harms from tobacco. This is particularly true for RYO where the industry has been able to proportionately add the most to their revenues per pack, and where there is evidence that RYO is relatively undertaxed. ${ }^{13}$

These findings imply that there is still scope to continue increasing tobacco taxes even in a high tax and price environment such as the UK. Such increases should be sudden and unexpected in order to have maximum impact. Furthermore, there is no evidence as yet that the industry's model of enhancing margins to offset declining sales is changing.

All countries and organisations involved in tobacco control should routinely monitor industry pricing in this way as a means of countering misleading tobacco industry arguments that tax increases drive illicit use. In reality, the tobacco industry wants to keep taxes low in order to be free to maximise their profits. Most countries have substantially lower tobacco taxation than the UK suggesting most will have huge scope for large unexpected increases in tobacco taxation. These will not only enhance public health by encouraging quitting but will likely enhance government revenues that can fund further health benefits.

Contributors All authors have participated sufficiently in the intellectual conception and design of this work, the acquisition and analysis of the data, and the writing and final approval of the manuscript, to take joint public responsibility for it.

Funding This project is funded by the National Institute for Health Research (NIHR) Public Health Research (PHR) programme (grant number 13/43/58). NIHR is funded by the UK Department of Health to improve the health and wealth of the nation through research.
Disclaimer The views and opinions expressed therein are those of the authors and do not necessarily reflect those of the Public Health Research programme, NIHR, NHS or the Department of Health. TRP, AG, RH and AM are members of the UK Centre for Tobacco and Alcohol Studies, a UK Clinical Research Collaboration Public Health Research: Centre of Excellence, whose work is supported by funding from the Medical Research Council, British Heart Foundation, Cancer Research UK, Economic and Social Research Council and the National Institute for Health Research under the auspices of the UK Clinical Research Collaboration (MR/ K023195/1). The responsibility for any errors lie solely with the authors.

Competing interests None declared.

Patient consent for publication Not required.

Provenance and peer review Not commissioned; externally peer reviewed.

Open access This is an open access article distributed in accordance with the Creative Commons Attribution Non Commercial (CC BY-NC 4.0) license, which permits others to distribute, remix, adapt, build upon this work non-commercially, and license their derivative works on different terms, provided the original work is properly cited, appropriate credit is given, any changes made indicated, and the use is non-commercial. See: http://creativecommons.org/licenses/by-nc/4.0/.

\section{ORCID iDs}

J Robert Branston http://orcid.org/0000-0002-2332-2403

Timea R Partos http://orcid.org/0000-0002-4049-9200

Ann McNeill 0000-0002-6223-4000

Sara C Hitchman 0000-0001-6155-6916

\section{REFERENCES}

1 World Health Organization. Effectiveness of Tax and Price Policies for Tobacco Control. In: IARC handbooks of cancer prevention in tobacco control. 14, 2011.

2 World Health Organization. WHO report on the global tobacco epidemic, 2017: monitoring tobacco use and prevention policies; 2017.

3 Chaloupka FJ, Yurekli A, Fong GT. Tobacco taxes as a tobacco control strategy. Tob Control 2012;21:172-80.

4 Tobacco Manufacturers' Association. Tobacco taxation in the UK, 2017. Available: http://www.the-tma.org.uk/wp-content/uploads/2017/02/TMA-Taxation_Briefing_ final.pdf

5 Tobacco Manufacturers' Association. TMA autumn budget response, 2017. Available: http://the-tma.org.uk/2017/11/22/tma-autumn-budget-response/

6 Gilmore AB, Reed $\mathrm{H}$. The truth about cigarette price increases in Britain. Tob Control 2014;23:e15-16.

7 Howell F. The Irish tobacco industry position on price increases on tobacco products. Tob Control 2012;21:514-6.

8 Gilmore AB, Gallagher AWA, Rowell A. Tobacco industry's elaborate attempts to control a global track and trace system and fundamentally undermine the illicit trade protocol. Tob Control 2019;28:127-40.

9 Gilmore AB, Branston JR, Sweanor D. The case for OFSMOKE: how tobacco price regulation is needed to promote the health of markets, government revenue and the public. Tob Control 2010;19:423-30.

10 Branston JR, Gilmore AB. The case for Ofsmoke: the potential for price cap regulation of tobacco to raise $f 500$ million per year in the UK. Tob Control 2014;23:45-50.

11 Eriksen M, Mackay J, Ross H. The tobacco atlas. 4th edition. American Cancer Society, 2013.

12 Office for National Statistics. RPI: Ave price - Cigarettes 20 king size filter 2018.

13 Branston JR, McNeill A, Gilmore AB, et al. Keeping smoking affordable in higher Tax environments via smoking thinner roll-your-own cigarettes: findings from the International tobacco control four country survey 2006-15. Drug Alcohol Depend 2018:193:110-6.

14 Hiscock R, Branston JR, McNeill A, et al. Tobacco industry strategies undermine government Tax policy: evidence from commercial data. Tob Control 2018;27:488-97.

15 HM Revenue \& Customs. Measuring Tax gaps 2017 edition: tobacco Tax gap estimates for 2016-17 2017.

16 Euromonitor Passport. EU plans higher cigarette prices to curb smoking 2008.

17 Gilmore AB, Tavakoly B, Taylor G, et al. Understanding tobacco industry pricing strategy and whether it undermines tobacco Tax policy: the example of the UK cigarette market. Addiction 2013;108:1317-26.

18 HM Revenue \& Customs. Tobacco Bulletin - July 20162016.

19 HM Revenue \& Customs. Value Added Tax (VAT) Bulletin - July 20162016.

20 Office for National Statistics. UK consumer price inflation: OCT 20162016.

21 HM Revenue \& Customs. Spot rates on 31 December 2010 and 31 March 20112019

22 HM Revenue \& Customs. Spot rates on 31 December 2013 and 31 March 20142019. 


\section{Correction: UK tobacco price increases: driven by industry or public health?}

Hiscock R, Branston JR, Partos TR, et al. UK tobacco price increases: driven by industry or public health?.Tob Control 2019;28:e148-50.doi:10.1136/tobaccocontrol-2019-054969.

In the original article there was an error in the calculation of Value Added Tax (VAT). We calculated the VAT sales tax that is applicable to tobacco sales in the UK as a proportion of the final sales price rather than as a proportion of the pre-VAT price, leading to a slight overestimation of the size of the tax and hence an underestimation of the industry's revenues. This error does not change the fundamental result or substance of the paper. For instance, we originally estimated the total tax increase of a 20 stick packet of premium cigarettes between 2013-15 was $£ 0.76$, but we now know it should in fact have been $£ 0.71$ due to our inadvertent over-estimation of the VAT due. The impact of this was that industry revenue actually increased by $£ 0.58$ as opposed to the original estimate of $£ 0.53$. The split between tax/industry source of the price increase therefore changed from our original estimate of $59 \%$ tax $41 \%$ industry price rises, to $55 \% / 45 \%$.

The results section therefore should read as follows:

\section{RESULTS}

In 2010-2012, the proportion of the price increase attributable to tax increases and industry price/revenue increases did not differ substantially by price segment or product type (despite tax and price increases being greater, in absolute terms, for FM than for RYO). For both FM and RYO increases in industry revenue accounted for about a quarter of the total price increase with little variation (20\%-28\%), and government revenues for the remainder ( $75 \%)$.

In 2013-2015, however, the patterns were quite different. First, government tax, industry revenue and total price increases varied much more substantially by price segment. Larger absolute tax and price increases were seen in higher price segments for both FM and RYO. Furthermore, the impact of the differential tax increases was exacerbated by industry actions, with the industry adding 58 pence to the price of FM premium brands but cutting subvalue brands' prices by four pence, and in RYO adding 36 pence to RYO premium but only 16 pence to RYO value. Consequently, a nearly two-fold difference in tax increase (41p (FM subvalue) to $71 \mathrm{p}$ (FM premium)) translates to a more than threefold difference in price increase ( $37 \mathrm{p}$ to $£ 1.29$, respectively) between FM segments. The percentage increase in overall total FM and overall total RYO price attributable to increases in industry revenue was higher in this period than the previous period. On average, about a third of the price increase for FM was industry revenue (compared with $23 \%$ in the previous period), while about half of the increase for RYO was industry revenue (compared with $27 \%$ in previous period).

A revised table 1 is presented below:

Table 1 Weighted Real price changes in pack revenue and tax-popular pack sizes in UK 2010-2015

\begin{tabular}{|c|c|c|c|c|c|}
\hline & $\begin{array}{l}\text { Total price } \\
\text { increase }\end{array}$ & $\begin{array}{l}\text { Government tax } \\
\text { increase }\end{array}$ & $\begin{array}{l}\text { Tobacco industry } \\
\text { revenue increase }\end{array}$ & $\begin{array}{l}\% \text { of price change that } \\
\text { is government tax }\end{array}$ & $\begin{array}{l}\% \text { of price change that is } \\
\text { tobacco industry revenue }\end{array}$ \\
\hline \multicolumn{6}{|l|}{ Jan 2010 to Dec $2012^{*}$} \\
\hline FM premium 20 stick & $£ 0.91$ & $f 0.67$ & f0.24 & $74 \%$ & $26 \%$ \\
\hline FM mid price 20 stick & f0.96 & $£ 0.74$ & $f 0.22$ & $77 \%$ & $23 \%$ \\
\hline FM value 20 stick & f1.12 & $£ 0.87$ & $£ 0.25$ & $78 \%$ & $22 \%$ \\
\hline FM value 19 stick & £0.95 & $\mathrm{f} 0.70$ & f0.19 & $80 \%$ & $20 \%$ \\
\hline Total FM† & & & & $77 \%$ & $23 \%$ \\
\hline RYO premium $12.5 \mathrm{~g}$ & f0.58 & $£ 0.43$ & f0.14 & $75 \%$ & $25 \%$ \\
\hline RYO mid price $12.5 \mathrm{~g}$ & $\mathrm{f} 0.60$ & $£ 0.43$ & $\mathrm{f} 0.17$ & $72 \%$ & $28 \%$ \\
\hline RYO value $12.5 \mathrm{~g}$ & f0.55 & $f 0.42$ & f0.13 & $76 \%$ & $24 \%$ \\
\hline Total RYO† & & & & $73 \%$ & $27 \%$ \\
\hline \multicolumn{6}{|l|}{ Jan 2013 to Dec $2015 \ddagger$} \\
\hline FM premium 20 stick & f1.29 & $£ 0.71$ & $f 0.58$ & $55 \%$ & $45 \%$ \\
\hline FM mid price 20 stick & f1.08 & $£ 0.66$ & 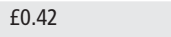 & $61 \%$ & $39 \%$ \\
\hline FM value 19 stick & $£ 0.83$ & $£ 0.60$ & $£ 0.23$ & $73 \%$ & $27 \%$ \\
\hline FM sub value 19 stick & f0.37 & $£ 0.41$ & $-f 0.04$ & $112 \%$ & $-12 \%$ \\
\hline Total FM† & & & & $64 \%$ & $36 \%$ \\
\hline RYO premium $12.5 \mathrm{~g}$ & $£ 0.64$ & $£ 0.28$ & $f 0.36$ & $44 \%$ & $56 \%$ \\
\hline RYO mid price $12.5 \mathrm{~g}$ & $£ 0.55$ & $f 0.26$ & $\mathrm{f} 0.28$ & $48 \%$ & $52 \%$ \\
\hline RYO value $12.5 \mathrm{~g}$ & f0.39 & $\mathrm{f} 0.24$ & $\mathrm{f} 0.16$ & $61 \%$ & $39 \%$ \\
\hline
\end{tabular}


Total price Government tax Tobacco industry \% of price change that \% of price change that is increase increase revenue increase is government tax tobacco industry revenue

Total RYO†

$52 \%$

${ }^{*}$ As of 31 March $2011 \mathrm{f} 1=\mathrm{US} \$ 1.603 .21$.

†As of 31 March $2014 \mathrm{f1}=\mathrm{US} \$ 1.6672 .22$

¥Weighted for volume, popular pack sizes only.

FM, factory-made cigarettes; RYO, roll-your-own tobacco.

\section{OPEN ACCESS}

Open access This is an open access article distributed in accordance with the Creative Commons Attribution Non Commercial (CC BY-NC 4.0) license, which permits others to distribute, remix, adapt, build upon this work non-commercially, and license their derivative works on different terms, provided the original work is properly cited, appropriate credit is given, any changes made indicated, and the use is non-commercial. See: http://creativecommons.org/licenses/by-nc/4.0/.

(C) Author(s) (or their employer(s)) 2021. Re-use permitted under CC BY-NC. No commercial re-use. See rights and permissions. Published by BMJ.

Tob Control 2021;30:e171-e172. doi:10.1136/tobaccocontrol-2019-054969corr1

(D) Check for updates 